\title{
United States and European Students' Social-Networking Site Activities and Academic Performance
}

Citation for published version (APA):

Karpinski, A., Kirschner, P. A., Shreffler, A., Albert, P., \& Tomko, C. (2016). United States and European Students' Social-Networking Site Activities and Academic Performance. International Journal of Cyber Behavior, Psychology and Learning, 6(1), 1-26. https://doi.org/10.4018/IJCBPL.2016010101

\section{DOI:}

10.4018/IJCBPL.2016010101

Document status and date:

Published: 01/01/2016

Document Version:

Other version

Please check the document version of this publication:

- A submitted manuscript is the version of the article upon submission and before peer-review. There can be important differences between the submitted version and the official published version of record. People interested in the research are advised to contact the author for the final version of the publication, or visit the DOI to the publisher's website.

- The final author version and the galley proof are versions of the publication after peer review.

- The final published version features the final layout of the paper including the volume, issue and page numbers.

Link to publication

\section{General rights}

Copyright and moral rights for the publications made accessible in the public portal are retained by the authors and/or other copyright owners and it is a condition of accessing publications that users recognise and abide by the legal requirements associated with these rights.

- Users may download and print one copy of any publication from the public portal for the purpose of private study or research.

- You may not further distribute the material or use it for any profit-making activity or commercial gain

- You may freely distribute the URL identifying the publication in the public portal.

If the publication is distributed under the terms of Article 25fa of the Dutch Copyright Act, indicated by the "Taverne" license above, please follow below link for the End User Agreement:

https://www.ou.nl/taverne-agreement

Take down policy

If you believe that this document breaches copyright please contact us at:

pure-support@ou.nl

providing details and we will investigate your claim.

Downloaded from https://research.ou.nl/ on date: 26 Apr. 2023 


\title{
United States and European Students' Social-Networking Site Activities and Academic Performance
}

\author{
Aryn C. Karpinski, Kent State University, Kent, OH, USA \\ Paul A. Kirschner, Open University of the Netherlands, Heerlen, The Netherlands \\ Anthony V. Shreffler, Kent State University, Kent, OH, USA \\ Patricia A. Albert, Kent State University, Kent, OH, USA \\ Carrie A. Tomko, Kent State University, Kent, OH, USA
}

\begin{abstract}
Different cultures communicate differently. Research is beginning to examine the differences in culture related to social-networking site (SNS) use. Differences in specific SNS activities related to academic performance among United States (US; $n=446)$ and European $(n=394)$ university students were examined. Moderated Multiple Regressions indicated that using SNSs for "career" and "school" were positively predictive of Grade Point Average (GPA) for both US and European students. For US students, "staying in touch with online friends" was negatively predictive. Results highlight the positive and negative relationships between various SNS activities and GPA, but specifically the use of SNSs for academic versus socialization purposes cross-culturally.
\end{abstract}

\section{KEYWORDS}

Academic Achievement, Country, Cross-Cultural Comparisons, Interaction, Moderated Multiple Regression, Multitasking, Online Social Networking, Post-Secondary Education, Socialization

\section{INTRODUCTION}

In the United States (US), people spend an extensive amount of time online (comScore, Inc., 2013a) on desktop, and increasingly mobile, platforms (comScore, Inc., 2014). Approximately one in every five minutes spent online is on social-networking sites (SNSs). Facebook ${ }^{\circledR}$, for example, is third in worldwide website rank, accounting for five out of every six minutes spent on SNSs. Since its inception, Facebook $^{\circledR}$ monthly active users have increased to 2.2 billion as of July 2014 (Edwards, 2014).

As it stands today, there are only seven cultural markets where Facebook ${ }^{\circledR}$ is not the leading social network, highlighting its global reach. In the US over the past year, the top visited web properties were Google $^{\circledR}$ (191,363 unique visitors) followed by Yahoo (184,935 unique visitors), Microsoft Sites ${ }^{\circledR}$ $(168,899)$, and Facebook ${ }^{\circledR}(149,602)$; however, Facebook ${ }^{\circledR}$ led in engagement with $10.8 \%$ minutes spent online out of all websites, and a dominant $83 \%$ of time out of all other SNSs (comScore, Inc., 2013a). In Europe (EU) in 2012, 408.3 million people used the Internet with their home or work computer (comScore, Inc., 2013b). The top visited web properties included Google ${ }^{\circledR}(375,260$ unique visitors) followed by Facebook ${ }^{\circledR}$ (275,882 unique visitors). Additionally, 6.7 hours per person per month were spent on social media sites (i.e., social networks and blogs). 